\title{
Correction to: Impacts of Migratory Sandhill Cranes (Grus canadensis) on Microbial Water Quality in the Central Platte River, Nebraska, USA
}

\author{
Jason R. Vogel · Dale W. Griffin • Hon S. Ip • Nicholas J. Ashbolt • \\ Matthew T. Moser · Jingrang Lu • Mary K. Beitz $\cdot$ Hodon Ryu • \\ Jorge W. Santo Domingo
}

Published online: 5 February 2022

(C) Springer Nature Switzerland AG 2022

Correction to: Water Air Soil Pollut (2013) 224:1576
https://doi.org/10.1007/s11270-013-1576-3

Any use of trade, firm, or product names is for descriptive purposes only and does not imply endorsement by the U.S. Government.

Publisher's Note Springer Nature remains neutral with regard to jurisdictional claims in published maps and institutional affiliations.

The original article can be found online at https://doi.org/ 10.1007/s11270-013-1576-3.

J. R. Vogel $(\bowtie) \cdot$ M. K. Beitz

Biosystems and Agricultural Engineering, Oklahoma State University, Stillwater, OK 74078, USA

e-mail: jason.vogel@okstate.edu

D. W. Griffin

USGS Florida Integrated Science Center, 600 4th Street

South, St. Petersburg, FL 33701, USA

H. S. Ip

USGS National Wildlife Health Center, 6006 Schroeder

Rd, Madison, WI 53711, USA

N. J. Ashbolt · J. Lu $\cdot$ H. Ryu $\cdot$ J. W. S. Domingo Office of Research and Development, U.S. EPA, Cincinnati, OH 45268, USA

M. T. Moser

USGS Nebraska Water Science Center, 5231 South 19th

Street, Lincoln, NE 68512, USA 